\title{
The importance of being Ernest
}

\author{
Creating a sustainable future based on clean energy from renewable sources is the challenge facing \\ incoming US energy secretary Ernest Moniz. Elsewhere in the world, progress is already being made.
}

In northern Europe, spring has finally sprung - although winter still continues elsewhere in the Northern Hemisphere (witness the snowed-in delegates at the American Physical Society's April Meeting). The delayed onset of the cheering warmer weather is a consequence of unusual contortions of the polar jet stream: writing in Environmental Research Letters, Qiuhong Tang and colleagues ${ }^{1}$ link this disruption to the diminishing area, measured over more than three decades, of winter sea ice in the Arctic. The planet and its climate are changing.

It's a challenge to all humankind, a responsibility on the shoulders of world leaders and their chosen staff - one of whom is Ernest Moniz, nominated by President Obama to take over the role of US Secretary of Energy from Nobelwinning physicist Steven Chu. Moniz is also a physicist, at Massachusetts Institute of Technology (MIT), but one whose career has taken in stints as Associate Director for Science in the Office of Science and Technology Policy and as Undersecretary in the Department of Energy (DOE) under the Clinton administration.

Since 2001, as Moniz described during his Senate confirmation hearing ${ }^{2}$ last month, his "principal focus has been at the intersection of energy technology and policy, especially on research and education aimed at a future lowcarbon economy”. In 2006, he was appointed founding Director of the MIT Energy Initiative $^{3}$, which encompasses scientific research, policy studies and education, as well as campus energy management. Moniz would seem to have exceptional experience - of energy matters and of Washington - that should equip him well for the role of energy secretary (and confirmation of his appointment by the Senate was expected as Nature Physics went to press).

Moniz has committed himself to Obama's promise of "an all-of-the-above strategy for the twenty-first century that develops every source of American-made energy." The DOE, he says, will support a "robust" portfolio of research and development, to include renewable and nuclear energy, efficiency and energy storage. To that end, the President has added an extra US $\$ 1$ billion for the DOE to his 2014 budget request, representing an $8 \%$ increase on
2012 funding levels - considerably above the $1 \%$ rise pencilled in for research and development overall.

There are, however, voices of dissent, who have questioned Moniz's connections to the energy industry - companies such as BP and Shell are among the 'founding members' of the MIT Energy Initiative and his support for the exploitation of shale gas (often extracted through the environmentally controversial process of 'fracking') in "advancing a clean energy system". The expansion of natural-gas production in the USA in recent years has indeed led to reduced coal consumption, and hence reduced greenhouse gas emissions - all well and good, yet that coal, and those emissions, have instead been exported to other parts of the world. Pushing the problem around doesn't solve it. Also last month, the European Parliament voted against a plan to boost carbon trading among the EU member states, over concerns that European businesses would find themselves at a competitive disadvantage to their US counterparts who are enjoying cheaper energy, largely thanks to the shale gas.

Energy - demand, consumption and the consequent impact on climate - is a global issue. But one country is going it alone. Germany is in the throes of an energy revolution - die Energiewende 4 - aiming to replace fossil fuels with renewable energy sources to mitigate the threat of climate change. Chancellor Angela Merkel and her government have set stiff targets for the reduction of greenhouse gas emissions. Those targets have become yet more stringent following the closure of eight nuclear power plants in the aftermath of the Fukushima incident in Japan in 2011; the remaining nine plants will close by 2022 .

Germany plans to generate $35 \%$ of its electricity from green sources by 2020 , more than $80 \%$ by 2050 , and is currently investing $€ 1.5$ billion per year in energy research. Between 2011 and 2014, €200 million will be spent on exploring the possibilities for energy storage: wind turbines and solar cells are of little use on still, cloudy days; and few nations would want to find themselves reliant on power carried over grids from sunnier, but perhaps politically less stable, regions of the world. Hence the $€ 3.5$ million investment in the 'power to gas' (P2G) pilot plant in Stuttgart: electricity generated using wind or solar power is used to produce methane from water and carbon dioxide; the methane can then be stored for energy use when insufficient power is available from the renewable sources.

\section{Germany plans to generate $35 \%$ of its electricity from green sources by 2020 , and more than $80 \%$ by 2050 .}

The total cost of Germany's Energiewende is expected to exceed $€ 1$ trillion, and, to support the programme, German consumers are now paying some of the highest energy prices in Europe. Given the straitened economic circumstances in Europe at present, it will take huge political will and continuing popular support to see the changeover through. But if Germany succeeds, it will have set a path for the world to follow. Moniz and his counterparts worldwide should keep track of its progress.

In a recent newspaper interview ${ }^{5}$, Jeremy Grantham offers an interesting perspective. Grantham is the co-founder of US-based global investment group GMO, and has also been dubbed the "world's most powerful environmentalist" for his personal investment in the Grantham Foundation for the Protection of the Environment. Asked about the priorities for his foundation, Grantham replied, "If I had a magic wand, it would be energy storage. Secondly, alternative energy in general."

And, invoking a metaphor that Moniz and all physicists will understand, he urged, "Have a look at the Manhattan project. They did remarkable things. They stuck the brightest minds out in the desert. They were herding cats with great egos, but it worked. If we did that on alternative energy, we'd be home free."

\footnotetext{
References

1. Tang, Q., Zhang, X., Yang, X. \& Francis, J. A. Environ. Res. Lett. 8, 014036 (2013).

2. http://go.nature.com/bANHxX

3. http://mitei.mit.edu/

4. Schiermeier, Q. Nature 496, 156-158 (2013).

5. Hickman, L. The Guardian (12 April 2013); available via http://go.nature.com/otct9R
} 